\title{
The Usage of Extract of Purple Fleshed Sweet Potato (Ipomoea batatas L.) as Color of Lipstick
}

\author{
Rety Setyawaty*, Desi Nofiani, Dewanto \\ Pharmacy Academy of Kusuma Husada, Purwokerto, Central Java, Indonesia
}

\begin{abstract}
Purple fleshed sweet potato (Ipomoea batatas L.) is one of the natural ingredients that contain natural color pigments. The natural color pigments are anthocyanin. Anthocyanin is a water-soluble pigment which is naturally found in various type of plants. This study aimed to make lipstick preparations using the purple-fleshed sweet potato extract (Ipomoea batatas L.) as a natural dye. The method is used to get anthocyanin as a color of lipstick by using the maceration extraction method. The weight of the sample was 250 grams of dried fleshed purple sweet potato. The liquid for maceration was $95 \%$ ethanol. The condition of maceration was acidic by using $2 \%$ of citric acid. The filtrate of the maceration process must be evaporated. The basis of lipstick components consisted of cera alba, lanolin, cetyl alcohol, paraffin solid, oleum ricini, propylene glycol, and nipasol. The concentrations of fleshed purple sweet potato extract were $0 \%, 2.4 \%, 4.5 \%$ and $14.6 \%$. The result of the research showed that the lipstick was easy to apply, an unstable color, homogenous, melting point above $50^{\circ} \mathrm{C}, \mathrm{pH}$ of 6 , and all lipstick had a breaking point when loaded at 330 grams. Based on the obtained results, the extract of purple-fleshed sweet potato can be used as a pigment color in the manufacture of lipstick. However, additional materials are needed that can keep the color of lipstick stable.
\end{abstract}

Keywords: lipstick; lipstick components; maceration; Purple fleshed sweet potato (Ipomoea batatas L.)

\section{INTRODUCTION}

Indonesia is rich in various floras which can be used as a source of natural ingredients, one of which is purple sweet potato bulbs (Ipomoea batatas L.). Bulbs of purple sweet potato (Ipomoea batatas L.) can be used as a source of natural dyes. Natural color substances are increasingly needed because they are considered safer than synthetic dyes (Hanum, 2000).

Lipstick is used to beautify the lips with attractive colors, protect the lips from drying out, and can make a brighter color and disguise the bad on the shape of the lips (Mulyaningsing, 2012). Synthetic dyes can last longer on the lips, are more uniform, and cheaper than natural dyes. The dye that is often added is Rhodamin B, which is relatively cheap, and the color produced is relatively interesting. This color agent can cause irritation to the respiratory tract and is a carcinogenic substance, and liver damage (BPOM RI, 2007). The use of natural dyes on lipstick is one way to reduce the use of synthetic dyes on lipstick. Natural dyes are obtained from plants, animals, or mineral sources (Andarwulan \& Faradilla, 2012).

For this reason, we need to find alternative natural dyes such as anthocyanin. Anthocyanin is a class of flavonoid compounds that includes naturally soluble pigments. The pigments provide

*Corresponding author : Rety Setyawaty

Email : rety.setyawaty@gmail.com red, blue, violet, and also act as antioxidants $(\mathrm{Li}$, 2009). Anthocyanin is a natural dye that is widespread in plants. In this research, anthocyanin has been a concern to be used as a dye, because it is natural and healthy compared to synthetic dyes (Yamakawa et al., 2009).

Anthocyanin is a water-soluble pigment that is naturally found in various plants. As the name implies, this pigment gives color to flowers, fruits, and green plants. This pigment has been used as a natural dye in various food products and other applications (Kumalaningsih, 2006).

Anthocyanin comes from the Greek word "Anthos" which means flower and "kyanos" which means dark blue and is included in flavonoid compounds (Kumalaningsih, 2006). This anthocyanin concentration causes several types of purple yams to have different purple shades (Hardoko et al., 2010). The purple color of the tuber, the higher the anthocyanin content (Widjanarko, 2008).

Chemically all anthocyanins are derivatives of a single aromatic compound, cyanidin. At $\mathrm{pH}$ less than 2, anthocyanin is in the form of a cation, but at a slightly acidic $\mathrm{pH}$, the quinonoid form is formed. This form is oxidized rapidly by air and is easily damaged, therefore anthocyanin extraction is safely carried out in an acidic solution because anthocyanin is stable at $\mathrm{pH}$ 2 and a temperature of $50^{\circ} \mathrm{C}$ (Winarti, et al., 2008). In the solution which has the color acid 
Table I. Lipstick formulation (\%)

\begin{tabular}{lcccc}
\hline \multicolumn{1}{c}{ Composition } & I & II & III & IV \\
\hline Purple sweet potato tuber extract & 0 & 2.4 & 4.5 & 14.6 \\
Cera alba & 12 & 12 & 12 & 12 \\
Paraffin wax & 11.5 & 11.5 & 11.5 & 11.5 \\
Cetyl alcohol & 8 & 8 & 8 & 8 \\
Adeps lanae & 10 & 10 & 10 & 10 \\
Propylen glycol & 10 & 10 & 10 & 10 \\
Tween 80 & 8 & 8 & 8 & 8 \\
Talk & 20 & 20 & 20 & 20 \\
Nipasol & 0.2 & 0.2 & 0.2 & 0.2 \\
Oleum ricini & 25 & 25 & 25 & 25 \\
Aquadest ad & 100 & 100 & 100 & 100 \\
\hline
\end{tabular}

formed it will tend to be red (Wijaya et al., 2009).

One type of plant that content of anthocyanin was the extract of purple sweet potato tuber (Ipomoea batatas L.). Various studies suggest that anthocyanin in purple tuber has high stability compared to anthocyanin in other plants (Andarwulan \& Faradilla, 2012). The availability of abundant sweet potato plants in Indonesia causes these tubers to have the potential to be developed as dyes in lipstick preparations. The purpose of this study was to prove that purple sweet potato tuber extract (Ipomoea batatas L.) can be used as a natural dye in the manufacture of lipstick preparations.

\section{METHODOLOGY}

\section{Materials}

The sample used in this study was purple sweet potato (Ipomoea batatas L.) tuber extract which had sufficient harvest time in Tipar, Rawalo District, Banyumas Regency. While other chemicals, including $95 \%$ of ethanol, $4 \%$ of citric acid, cera alba, adeps lanae, cetyl alcohol, solid parrafin, oleum ricini, propylene glycol, nipasol, talc, and tween 80 .

\section{Methods}

\section{Determination of plants}

Determination of the Ipomoea batatas $\mathrm{L}$. plant aims to ensure that the sample was Ipomoea batatas L.

\section{Anthocyanin extractions}

A number of 250 grams of mashed purple sweet potato tubers were extracted with $500 \mathrm{~mL}$ $95 \%$ ethanol which acidified by $2 \%$ citric acid was added, until the $\mathrm{pH}$ of the solution was in the range 1-3 (Wijaya et al., 2009). Extraction was done by maceration for 3 days while stirring occasionally.
The ethanol extract obtained was collected. The collected extract was then evaporated using a water bath.

\section{Manufacturer of lipstick}

Solid paraffin, cera alba, adeps lanae, and cetyl alcohol were melted on the water bath at $50^{\circ} \mathrm{C}$ (Mass A). In the other solution, the extract and propylene glycol are mixed until homogeneous in the mortar. Add the talk and stir until homogeneous. Add nipasol and stir until homogeneous (Mass B). Castor oil was weighed and put into a heated mortar. Mass A which had melted was then poured, and homogenized with a warm stemper. Mass B was poured in a mortar that has been filled with castor oil. Mass A and B were poured into a heat porcelain dish, stirred using an iron spatel to melt perfectly. The mixture was poured into the mold. Lipstick preparations are made with the formulas listed in Table I.

\section{Evaluation of lipstick}

The test of the physical properties of lipstick preparations is the breaking point of lipstick, homogeneity test, smear test, melting point, $\mathrm{pH}$ test, and stability testing of lipstick color.

\section{Breaking point}

Observations are made when the lipstick is broken. The weight of a broken lipstick was breaking point value (Lauffer, 1985).

\section{Homogenous test}

Each lipstick preparation made from Jati leaf extract was examined for homogeneity by applying a certain amount of preparation on a transparent glass. The preparation should show a homogeneous arrangement and no visible coarse grains (Ditjen POM, 1979). 


\section{Smear test}

A smear test was done by applying the lipstick on the back of the hand then was observed the number of the colors attached to 5 times (Keithler, 1956).

\section{Melting point of lipstick}

The lipstick melting point was determined by heating the lipstick over the water bath in the container and a thermometer is placed in it to determine the temperature at which the lipstick melts (Chabib et al., 2000).

\section{pH test of lipstick}

Determination of the $\mathrm{pH}$ of lipstick was done by weighing 1 gram sample then melted over a water bath, after melting the $\mathrm{pH}$ stick and let it show the $\mathrm{pH}$ value of lipstick (Rawlins, 2003).

\section{Stability test}

The stability test of the lipstick was done at each dosage of lipstick. The aim of this test was to determine whether there is a change of forms, color, and smell during storage in room temperature for 1, 5, 10, 15, 20, 25 and 30 days (Vishwakarma, 2011).

\section{RESULTS AND DISCUSSION}

Determination of plants

The determination was carried out at the Plant Taxonomy Laboratory of the Faculty of Biology, Jendral Sudirman University. The results of the determination stated that the plants used in this study were true purple sweet potato (Ipomoea batatas L.).

\section{Anthocyanin extractions}

Based on the results of the study, the yield of thick extracts from the tubers of purple sweet potatoes was obtained by $12.5 \%$. The yield of extract produced in this study was more than $10 \%$ $(\mathrm{MOH}, 2018)$ due to the coarse particle size of purple sweet potato tubers. The size of the yield indicates the effectiveness of the extraction process. The effectiveness of the extraction process is influenced by the type of solvent, the size of the simplisia particles, and the period of the extraction (Permawati, 2008). The color of the extract was red (Figure 1). Anthocyanins give color purple, red, blue, or brown (Syah, 2005).

\section{Evaluation of lipstick}

The breaking point of lipstick

The lipstick was broken by a load that functions as a pressure. If a break occurs, it is a breaking point value (Risnawati, 2012). The breaking point of lipstick is influenced by the

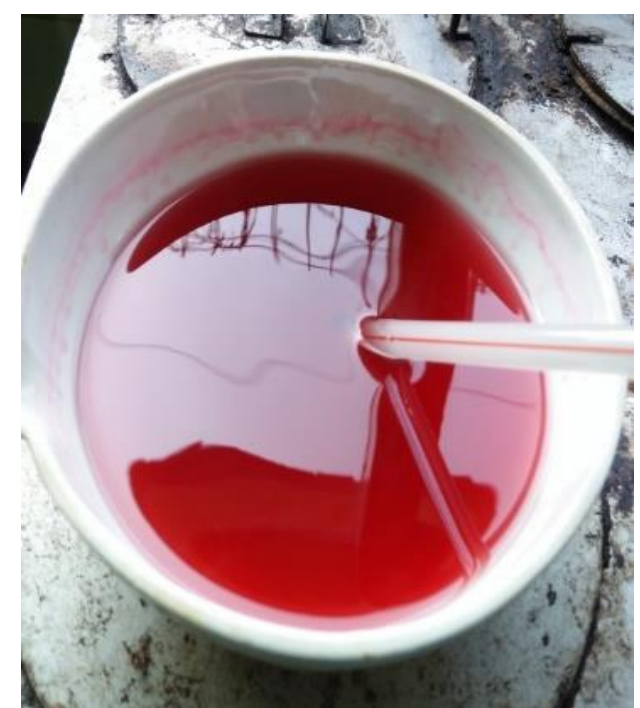

Figure 1. Results of extraction by $95 \%$ ethanol which is acidified by $2 \%$ of citric acid

composition of lanolin (Barel et al., 2001). Each lipstick contains adeps lanae $10 \%$. Adeps lanae are also called lanolin. Lanolin is often used in topical preparations and cosmetics. Adeps lanae is used as a carrier of hydrophobic substances and is a substance that is practically insoluble in water (Rowe et al., 2009). Adeps lanae is usually used as a moisturizer, increases the strength of the lipstick, and prevents the tendency of the oil to separate (Jellinek, 1970). The result of the breaking point test of lipstick can be seen in Table II.

Based on Table II, it can be seen that formula I showed the highest strength of 400 grams. Apparently, the addition of extract to the formula makes lipstick preparation weaker (break at the load of $330 \mathrm{~g}$ ). The large yield of thick extract $(12.5 \%)$ affects the strength of the lipstick.

\section{Homogeneity test}

Each lipstick preparation made from Purple fleshed sweet potato (Ipomoea batatas L.) extract was examined for homogeneity by applying a certain amount of preparation on a transparent glass. The preparation should show a homogeneous arrangement and no visible coarse grains (Ditjen POM, 1979).

The results of the homogeneity tests of the four formulas I, II, III, IV showed that all lipstick preparations did not show coarse grains when the lipstick is applied to transparent glass. This indicates that the lipstick made has a homogeneous arrangement (Ditjen POM, 1979).

\section{Smear test}

A topical test is done by applying lipstick on the back of the arm, then observing the number of 
Table II. Breaking point of lipstick

\begin{tabular}{cc}
\hline Formula & Breaking point (gram) \\
\hline I & 400 \\
II & 330 \\
III & 330 \\
IV & 330 \\
\hline
\end{tabular}

Table III. Results of Smear Test of Various Lipstick Formulas

\begin{tabular}{clcccc}
\hline \multirow{2}{*}{ Formula } & \multicolumn{4}{c}{ Parameter } \\
\cline { 2 - 6 } & Homogeneity & Texture & Luster & Sticky power & Sticking color \\
\hline I & Homogeneous & Rather smooth & Glitter & Sticky & There is no color attached \\
II & Homogeneous & Rather smooth & Glitter & Sticky & There is no color attached \\
III & Homogeneous & Rather smooth & Glitter & Sticky & There is no color attached \\
IV & Homogeneous & Rather smooth & Glitter & Sticky & There is no color attached \\
\hline
\end{tabular}

Table IV. Melting point analysis results

\begin{tabular}{cc}
\hline Formula & Melting point (可) \\
\hline I & 55 \\
II & 53 \\
III & 53 \\
IV & 53 \\
\hline
\end{tabular}

Table V. pH analysis results

\begin{tabular}{cc}
\hline Formula & pH \\
\hline I & 5 \\
II & 6 \\
III & 6 \\
IV & 6 \\
\hline
\end{tabular}

colors attached to the treatment with 5 times applying (Alfrida, 2016).

Based on the results of the analysis, it showed that all lipstick formulas did not show color on the skin, but the preparations remain homogeneous, textured rather smooth, have gloss, and were attached to the lips. These four lipstick formulas were more appropriately referred to as lip balm or lip gloss, because they did not give color to the lips, only give moisture and give a glossy effect on the lips. The results of the smear test can be seen in Table III.

\section{The melting point of lipstick}

Table IV shows the melting point of lipstick preparations. The formula I lipstick has a higher melting point than lipstick formulas II, III, and IV. This is due to the presence of cera alba and other lipstick bases and the absence of extracts so that it can increase the melting point of the lipstick (Afrida, 2016).
Based on the melting point value, the four lipstick formulas had a good melting point. According to SNI number 16-4769 (1998), that the melting point of lipstick is $50-70{ }^{\circ} \mathrm{C}$ (Alfrida, 2016). Furthermore, a good lipstick had a melting point above $50{ }^{\circ} \mathrm{C}$ (Vishwakarma et al., 2011).

pH test

$\mathrm{pH}$ testing is carried out to determine the $\mathrm{pH}$ level of the lipstick preparation. This is because $\mathrm{pH}$ has a relationship with skin irritation. If the $\mathrm{pH}$ of the lipstick is not in accordance with the $\mathrm{pH}$ of the skin it can increase the risk of irritation and cause an uncomfortable feeling on the skin. The normal human skin $\mathrm{pH}$ ranges from 4-6 (Ali and Yosipovitch, 2013).

Based on Table $\mathrm{V}$, the $\mathrm{pH}$ test results of lipstick preparations obtained $\mathrm{pH}$ that was in accordance with the $\mathrm{pH}$ of normal skin, where the $\mathrm{pH}$ test results in formulas I had a $\mathrm{pH}$ of 5 and formulas II to IV had a $\mathrm{pH}$ of 6 . If the $\mathrm{pH}$ of the 
Table VI. Stability test results for lipstick preparations

\begin{tabular}{|c|c|c|c|c|c|c|c|c|}
\hline \multirow{2}{*}{ Observation } & \multirow{2}{*}{ Formula } & \multicolumn{7}{|c|}{ Length of observation (Days) } \\
\hline & & 1 & 5 & 10 & 15 & 20 & 25 & 30 \\
\hline \multirow[t]{4}{*}{ Color } & I & W & W & $\mathrm{W}$ & $\mathrm{W}$ & $\mathrm{W}$ & W & $\mathrm{W}$ \\
\hline & II & $\mathrm{PF}$ & PF & $\mathrm{P}$ & $\mathrm{P}$ & $\mathrm{P}$ & $\mathrm{P}$ & $\mathrm{P}$ \\
\hline & III & SP & SP & $\mathrm{LC}$ & $\mathrm{LC}$ & $\mathrm{LC}$ & $\mathrm{LC}$ & $\mathrm{LC}$ \\
\hline & IV & PL & PL & $\mathrm{CN}$ & $\mathrm{CN}$ & $\mathrm{CN}$ & $\mathrm{CN}$ & $\mathrm{CN}$ \\
\hline \multirow[t]{4}{*}{ Odor } & I & DS & DS & DS & DS & DS & DS & DS \\
\hline & II & DS & DS & DS & DS & DS & DS & DS \\
\hline & III & DS & DS & DS & DS & DS & DS & DS \\
\hline & IV & DS & DS & DS & DS & DS & DS & DS \\
\hline \multirow[t]{4}{*}{ Shape } & I & $\mathrm{G}$ & $\mathrm{G}$ & $G$ & $\mathrm{G}$ & $\mathrm{G}$ & $\mathrm{G}$ & $\mathrm{G}$ \\
\hline & II & G & G & G & G & $\mathrm{G}$ & G & G \\
\hline & III & G & G & G & G & G & G & G \\
\hline & IV & $\mathrm{G}$ & G & G & G & $\mathrm{G}$ & G & $\mathrm{G}$ \\
\hline
\end{tabular}

Annotation: G: Good; DS: Distinctive Smell; CN: Chocolate Nude; LC: Light Cream; P: White; PL: Purple; SP: Soft Pink; PF: Pink Faded

lipstick is compared with the pH of normal skin, it can be said that the $\mathrm{pH}$ of the preparation is appropriate so that it can reduce the risk of irritation to the skin of the lips.

\section{Stability testing of lipstick}

Stability checks were made on changes in the shape, color, and smell of lipstick preparations made on each preparation during storage at room temperature on day 1, 5, 10 and then every 5 days until the 30th day (Vishwakarma et al., 2011).

The stability test results of lipstick preparations showed that all preparations were made unstable in storage at room temperature for 30 days of observation. The parameters observed in the physical stability test include changes in the shape, color, and smell of the preparation. This can be seen in Table VI.

All formulations of lipstick preparations still have a good shape and smell from day 1 to 30 . On day 10 there was a change in color from light beige to nude brown in Formula II, III, and IV. The color of lipstick was not stable in a storage test. It might be because of sugar content in the extract. As we know, purple sweet potato contains sucrose as the main sugar, fructose, glucose, and xylose. Those sugars increase the color degradation of anthocyanin by forming a polymer pigment and browning process. Moreover, anthocyanin itself is unstable and easily degraded. Its stability was reduced by sucrose (Chen et al., 2019).
The anthocyanin dyes are unstable and easily degraded. Its stability is influenced by $\mathrm{pH}$, storage temperature, light, enzymes, oxygenation, sugar, structural differences in anthocyanins, and concentrations of anthocyanins (Misra, 2008).

\section{CONCLUSION}

Extract of purple-fleshed sweet potato can be used as a pigment color in the manufacture of lipstick. Lipstick will break if given a load of 330 grams and melt above $50^{\circ} \mathrm{C}$. Lipstick has homogeneous characteristics and no change of odor and shape when the lipstick is kept until 30 days. The $\mathrm{pH}$ of the lipstick is made, present in lip $\mathrm{pH}$ conditions is 4-6. Lipstick on a formula of $2.4 \%$, $4.5 \%$, and $14.6 \%$ of extract purple sweet potato tuber does not display color on the skin. Moreover, the extract of purple-fleshed sweet potato contains sugar. Sugar causes pigment color unstable because anthocyanin is easily degraded.

\section{REFERENCES}

Alfrida, 2016, 'Mempelajari kestabilan dan efek iritasi sediaan lipstik yang diformulasikan dengan lemak kakao', Laporan Penelitian, Makasar, Balai Besar Industri Hasil Perkebunan.

Ali, S.M., \& Yosipovitch G., 2013, 'Skin pH: From Basic Science to Basic Skin Care', Acta Derm Venereol. 93, 261-267.

Andarwulan, N. \& Faradilla, F., 2012, Pewarna 
Alami Untuk Pangan. Bogor: Institut Pertanian Bogor.

Badan POM RI, 2007, Public Warning/Peringatan Tentang Kosmetik Mengandung Bahan Berbahaya dan Zat Warna yang Dilarang. Jakarta: BPOM

Barel, A.O., Paye, M., and Maibach, H.I., 2001, Handbook of Cosmetic Science and Technology. Informa Health Care, USA, pp. $392,409-410,670-671,773$.

Chabib L, Muhammad I.R., and Farida H., 2000, 'Formulasi Nanopartikel Karotenoid Ekstrak Wortel (Daucus Carrota L.) Sebagai Pewarna Lipstik', Laporan Penelitian, DPPM UII, 809-822.

Chen C.C., Lin C, Chen M.H., and Chiang P.Y., 2019, 'Stability and Quality of Anhocyanin in Purple Sweet Potato Extracts', Foods, 8(9), 393.

Ditjen POM, 1979, Farmakope Indonesia, $3^{\text {rd }}$ Edition, Jakarta, pp. 33, 459, 633.

Hanum. 2000. Ekstraksi dan stabilitas zat pewarna alam dari katul beras ketan hitam. Bulletin teknologi dan industri pangan.

Hardoko L, Hendarto, Siregar TM. 2010. 'Pemanfaatan ubi jalar ungu sebagai pengganti sebagian tepung terigu dan sumber antioksidan pada roti tawar (The use of purple sweet potato as a partial replacement for wheat flour and a source of antioxidants in white bread)'. Jurnal Teknologi Pangan, 21(1), 25-32.

Jellinek. 1970. Formulation and Function of Cosmetics, John Willey and Sons, Inc., USA, pp. 113-114, 121, 431.

Keithler. W. 1956. Formulaion of Cosmetics and Cosmetic Industry. pp 153-155.

Kumalaningsih, S, 2006, 'Antioksidan alami: penangkal radikal bebas (Natural antioxidants: free radicals)', Antioxidants Health aspects, Surabaya: Trubus Agrisana.

Lauffer, 1985, 'Kosmetik dan Pewarna pada Bibir (Cosmetics and Lip Color)', Jurnal Biologi Universitas Jendral Sudirman, 2 (3), 65-80.

Li, J., 2009, Total anthocyanin content in blue corn cookies as effected by ingredients and oven tipes, Diakses 28 Januari 2019. https: // krex.k-state.edu/dspace/bitscream/ handle/2097/1673/Jian-Li2009.pdf? sequence $=1>$.
MOH (Ministry of Health). 2008. Farmakope Herbal Indonesia (Indonesian Herbal Pharmacopoeia). Ministry of Health Republic of Indonesia. Jakarta

Mishra, D. K., K. D. Dolan, and L. Yang, 2008, 'Confidence Intervals for Modelling Anthocyanins Retention in Grape Pomace during Non Isothermal Heating', J Food Sci, 73(1), E9-15.

Mulyaningsih, Endang, 2012, Metode Penelitian Terapan Bidang Pendidikan, Yogyakarta: Alfabeta.

Permawati, M., 2008, Karakterisasi ekstrak air daun gandarusa Uusticia gendarussa burn F.) dan pengaruhnya terhadap kadar asam urat plasma tikus putih jantan yang diinduksi kalium oksonat, Thesis, Depok, University of Indonesia.

Rawlins, E.A. 2003. Bentley's Textbook of Pharmaceutics. 18th Edition, London, Bailierre Tindall, pp 355.

Riesnawati N., Purba D., 2012, 'Formulasi Lipstik Menggunakan Ekstrak Biji Coklat Sebagai Pewarna', Jurnal of Pharmaceutics and Pharmacology, 1(1), 78-86.

Rowe, R.C., Sheskey, P.J., and Quinn, M. E, 2009, Handbook of Pharmaceutical Exipients 6th $E d$, Pharmaceutical Press and American Pharmacists Association, United Kingdom, pp. 1, 283, 378-380, 549-550, 741-742, 779.

Syah, D. 2005. Manfaat dan Bahaya Bahan Tambahan Pangan. Skripsi. IPB. Bogor.

Vishwakarma, B., Sumeet Dwivedi, Kushagra Dubey, dan Hemant Joshi, 2011, Formulation And Evaluation of Herbal Lipstick, International Journal of Drug Discovery \& Herbal Research, India : Ujjain Institute of Pharmaceutical Sciences, Ujjain, (M.P), pp. 18-19.

Widjanarko, S, 2008, Efek Pengolahan terhadap Komposisi Kimia \& Fisik Ubi Jalar Ungu dan Kuning, Jakarta : Gramedia pustaka utama.

Wijaya, LA, MP Segara, Supriono F, 2009, Pemanfaatan Limbah Kulit Manggis sebagai pewarna alami antioksidan dengan menggunakan teknologi mikroenkapsulasi, Bogor: Institut Pertanian Bogor.

Winarti S, Sarosa U, Anggraeni D, 2008, 'Ekstraksi dan stabilitas warna ubi jalar ungu sebagai pewarna alami', Jurnal teknik kimia, 3(1), 207-214. 
Rety Setyawaty

Yamakawa, Y., Oosuna, H., Yamakawa, T., Aihara, M., \& Ikezawa, Z., 2009, 'Cochineal Extract
Induced Immediate Allergy', J Dermatology, 36(1), 72-4. 